\title{
MATERIALITY OF RURAL VERNACULAR HOUSING IN THE ANDEAN HIGHLANDS OF COLOMBIA: ENVIRONMENT AND BUILDING SYSTEMS
}

\author{
YARLEYS PULGARÍN OSORIO \\ Master and PhD Architecture Program, National Autonomous University of Mexico, Mexico
}

\begin{abstract}
The material expression of rural vernacular housing in the Andean highlands of Colombia is the result of a combination of American native's labour, materials and construction systems, and the techniques and spatiality of the European conquerors that arrived in the territory in the sixteenth century. Until today, from the indigenous population there still exist a few examples of wattle and daub, adobe walls and straw roofs, while from the Spaniards stems the adobe masonry and clay tile as the dominant expression, in which both building systems always appeal to the use of available raw materials (clay, wood and vegetable fibres). These architectural expressions remained unchanged until the end of the twentieth century when industrial materials were introduced, stimulated by the appearance of roadways that today reach what were once remote areas. Likewise, the dynamics of the market economy and national public sanitation policies led to the substitution of traditional construction systems and the progressive abandonment of these vernacular buildings. Thus, currently the total sample of the inhabited dwellings studied, in the rural area of six municipalities of the Andean Highlands of Colombia, have one or more volumes built with materials such as brick and asbestos-cement roof sheets. On the other hand, State housing programs and individual improving initiatives have contributed in some cases to preserve, consciously or unconsciously, the spatiality of ancient buildings. This has prevented the loss of some of its associated values, although, for this case study in particular, the low economic capacity of the rural homeowner and the above-mentioned State policies have had an impact on the choice of materials rather than the availability of raw materials found in the natural environment in which this housing is implanted, which is threatening the survival of old techniques.
\end{abstract}

Keywords: transculturation, raw materials, environment, building tradition, change.

\section{INTRODUCTION}

The vernacular rural housing architecture's main feature in the Andean highlands of Colombia is transculturation [1], expressed in an evident form in several typological traits as the use of certain materials and construction techniques, and the houses' spatial configuration. To affirm this idea, this case study has evaluated 97 domestic-use buildings with a variable antiquity between three and 120 years in an area formed by six municipalities (Arcabuco, Gachantivá, Ráquira, Sáchica, Sutamarchán and Tinjacá) and located $180 \mathrm{~km}$ northeast of Bogotá. There, $70 \%$ of the population $(60,000$ according to the National Administrative Statistics Department, DANE) occupy the rural zones.

There still remains a small sample of the indigenous (Muisca groups) architecture before Spaniards arrived in 1537 [2], mainly represented in some spatial patterns, materials and construction techniques that were transformed once they interacted with each other [3]-[8]. Historical images [9] evidence how this transculturation product remained unchanged for about four centuries and it represents a pragmatic and experience-developed wisdom; but the fieldwork reveals how it has been permeated in recent years by the arrival of technologies that are replacing some popular knowledge elements (see Fig. 1).

While it is true that vernacular rural housing in this area shares typological features with those near Bogotá and Colombia's southwest region [10], the particular environmental conditions of this zone have favoured the existence of local variations reflected in the use of certain materials and the applied knowledge by the builder in each specific case. 


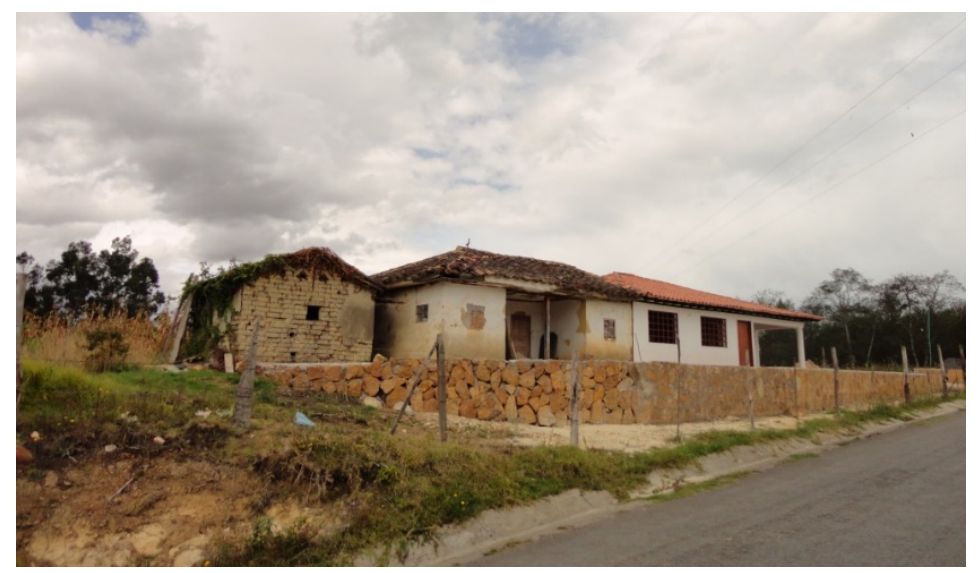

Figure 1: Exterior view of a house located on the road from Villa de Leyva to Gachantiva, exhibiting three construction phases, the earliest on the left and the latest on the right. This last stage incorporates industrial materials.

\section{GEOGRAPHICAL ENVIRONMENT}

The studied region includes six municipalities and comprises an area of approximately $1000 \mathrm{~km}^{2}$. It is a dry enclave located on the central Andean highlands surrounded by mountain ranges that retain humidity, within which there exist natural reserve areas and several water sources that are of great importance for the location of housing in rural areas (see Fig. 2). Besides, its variable topography between 2200 and 3800 meters above sea level enables the coexistence of three life zones [11]: Dry Forest, Rain Forest and Wet Forest. It should be noted, this topographical configuration allows a higher ambient temperature than it should be, around $17^{\circ} \mathrm{C}$ average in lowlands, and lack of rain in specific areas which are reflected by a low soil fertility in much of the region.

The ecosystems and specific vegetation associated with these life zones have favoured the existence of several species, which have been traditionally used in housing construction (tie up, walls, roof structures, columns) such as Furcraea cabuya, Stipa ichu, Alnus acuminata, Baccharis macranta, Weinmannia tormentosa, Arundo donax, Miconia sp., Myrsine guianensis, Salix humboldtii, Dodonea viscosa, Quercus humboldtii and Podocarpus oleifolius among other such as Eucalyptus globulus [12] which was introduced around two hundred years ago.

The soil composition of this zone also adds particular features to the raw materials used in differently developed techniques; an analysis of several adobe samples collected in the studied area revealed a relative clay-low proportion, in comparison with the sand and silt percentage. Additionally, some municipalities' adobe and wattle and daub walls exhibit yellow and grey tonalities, contrasting with the brown colour we could find in other zones of Colombia.

Likewise, the location of a house in a particular life zone defines its relationship with the natural environment, which is reflected by its volumetric configuration and the use of its spaces. In effect, when comparing Rain Forest houses and Wet Forest houses, it was possible to determine that the typological differences between them are minimal, while there are visible differences between the latter and those houses located in the Dry Forest, which are singular due to their construction systems and ground implantation. 

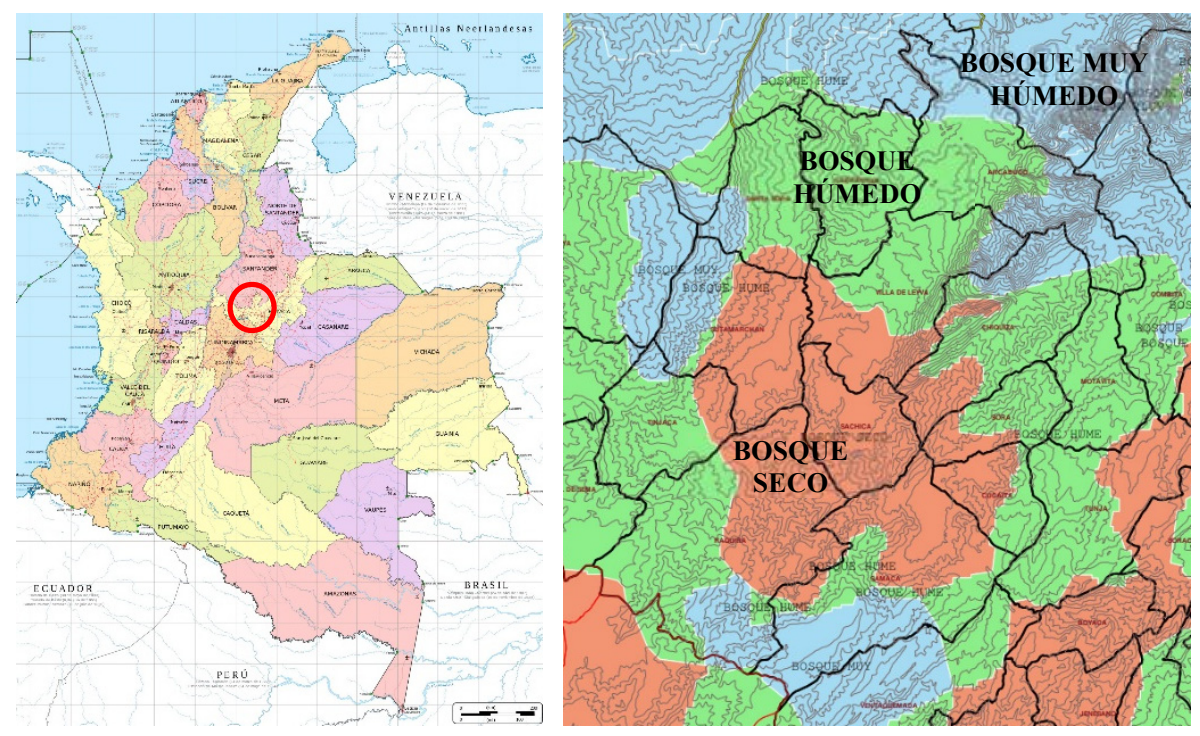

Figure 2: Location of the studied zone in Colombia (left) and delimitation of the life zones in the municipalities: Dry Forest - Bosque Seco, Rain Forest - Bosque Húmedo and Wet Forest - Bosque Muy Húmedo (right). (Source: https://commons.wiki media.org/wiki/File:Colombia_Mapa_Oficial.svg and SIGTER Boyacá.)

\section{TRADITIONAL MATERIALS AND CONSTRUCTION SYSTEMS}

In this region, $68 \%$ of houses visited were built by their homeowners or were inherited. Using as a basis the results of the National Agricultural Census (2014), it was established that there are approximately 14,500 rural dwellings; $26 \%$ use traditional systems as wattle and daub and adobe masonry as the principal material, while $65 \%$ have already incorporated industrial systems such as hollow and solid brick masonry.

The 97 houses visited were conformed either by one or more volumes and were built by traditional systems; the fieldwork evidences that the above-mentioned systems were used in the three life zones: $37 \%$ of houses are located in the Dry Forest, $45 \%$ in the Rain Forest and $18 \%$ in the Wet Forest. This data is proportional to the area of each life zone in the studied area.

Houses with one or more volumes built with wattle and daub technique represent $20.3 \%$ of the total sample, and half of them are located in the Dry Forest, while those constructed with adobe masonry reach $88 \%$. Houses using stone masonry represent $12.9 \%$, and are mainly located in the Dry Forest. By contrast, $76 \%$ of the total sample has volumes built with industrial materials, such as the brick.

For the region's inhabitants, materials and building systems are an indicator of the homeowner's economic level as well as the stage of the construction process. For this, raw materials from the surrounding were first used, and the sequence of construction systems began by stone masonry or wattle and daub walls. As homeowners' economic status improved, these systems were replaced by adobe masonry and, most recently, by the use of industrial materials. These results have been corroborated by previous studies as carried out by Fonseca and Saldarriaga [10], who point out that "it is evident that rural construction 
technology and architecture of housing are problems related with regional economy and culture problems, that is to say, they are not independent".

In this case study, the transmission of knowledge about the management of traditional materials and techniques appeals to what Anderson [13] calls "Social Memory", typical of human groups where writing is not a dominant media. This way, orally, the building transforms itself into a document which new generations use to learn, and at the same time the building is capable of rewriting itself, because memory can mutate every time a new construction appears. It is collective knowledge [14] that over the years has become the most effective environment domain tool used by human groups [15].

Construction times vary according to the technique, area of buildings and number of people involved in the process. Usually, a builder with knowledge on traditional building systems is hired, and may be joined by peasants as well; for each house they will have a singular way to solve construction details, especially in roof structure and masonry rigs, where they set a mark that discloses their identity. Thereafter, family members participate in several tasks along the process: amassing mud, cutting adobe, tying wood, carrying water or raw materials or preparing food for the participants.

The presence or absence of exterior finishing with lime or cement plastering has an influence on the way a building is perceived from a distance. For instance, the absence of an exterior finishing allows those houses located in the Dry Forest to camouflage with their environment, in contrast with those located in other life zones.

The uses of the raw materials and building systems also have an incidence in geometry and spaces dimension, which are naturally governed by the laws of physics and unconsciously incorporated after years of practice by builders and homeowners of rural vernacular houses. In effect, this incidence is reflected in small windows and doors and a restricted length-height of walls.

\subsection{Wattle and daub (bahareque)}

This is the cheapest building system used in rural vernacular housing of this zone, as it does not need more materials than those that nature provides (see Fig. 3). Despite the damage water can produce on wattle and daub walls, examples of houses in which this technique was used were found in the three life zones [16]. In all the houses, the walls are conformed by a
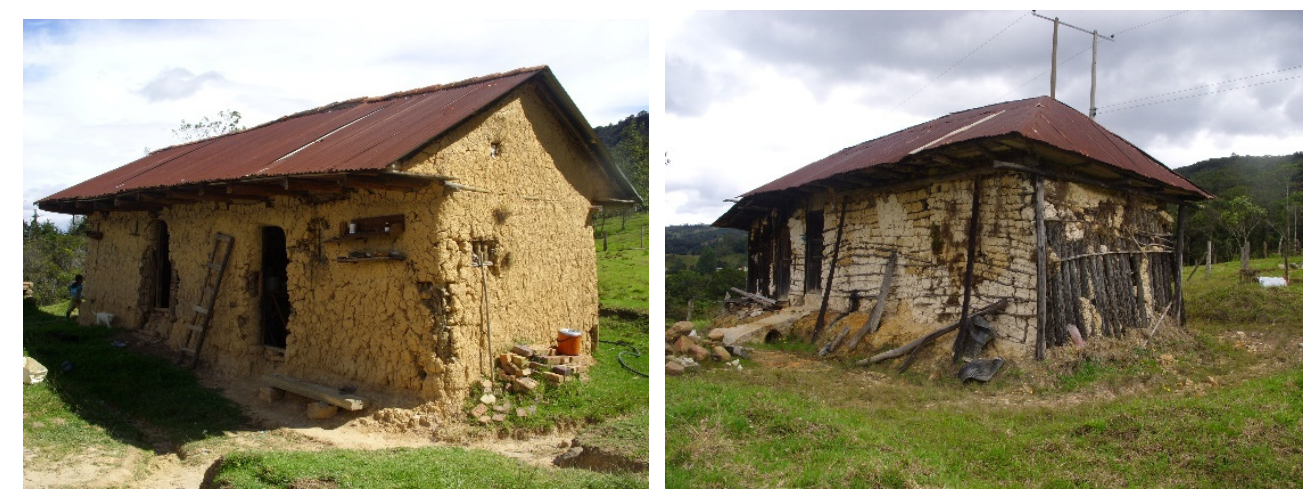

Figure 3: Uses of the wattle and daub walls in the Rain Forest in the municipalities of Tinjacá (left) and Arcabuco (right), using local wood from each life zone. Currently, these buildings are abandoned. 
vertical wooden stake structure (wattle), on whose facade rests a framework of horizontal elements of a smaller dimension; the vegetal fibre used to make wattle is Arundo donax, which comes from lowlands. Treated mud will be poured within the wooden panels formed by the wattle and another layer of mud will also be applied to the front exposed to the weather. Some $20.3 \%$ of the dwellings visited were built with this technique, and approximately half were located in the Dry Forest.

\subsection{Adobe masonry}

According to several testimonies of the inhabitants of the houses that were visited, adobe used for building was made mostly with mud from the property or its vicinity. Soils used are composed of alumina-silicate, and all the adobe blocks have a rectangular form and a proportion between 1-1/2-1/4 length-height-deep. Not all of them have the same tonality, as they vary between grey in the municipality of Arcabuco, yellow in Gachantivá and brown in the other municipalities (see Fig. 4). Kaolinite, or other minerals that help to increase the resistance of the adobe blocks, were not detected.

Tests on four adobe samples [17] revealed a proportion of vegetal fibres and minerals in relation with the mud of the mixture of 1 to 10 in one case and 1 to 20 in two cases. Also in one sample, there was an insignificant presence of vegetal fibres, but a presence of granular lytic aggregates in a ratio of 1 to 2 in relation with the mud.

For adobe production, hollow and shallow wooden frames of different sizes are used, in which a mixture composed of previously soaked, treated mud, and the aggregates are deposited. After two days, and with the help of a knife, the frames are removed and the adobe blocks are put to dry; drying time can vary between two days in the Dry Forest and two weeks in the Wet Forest.

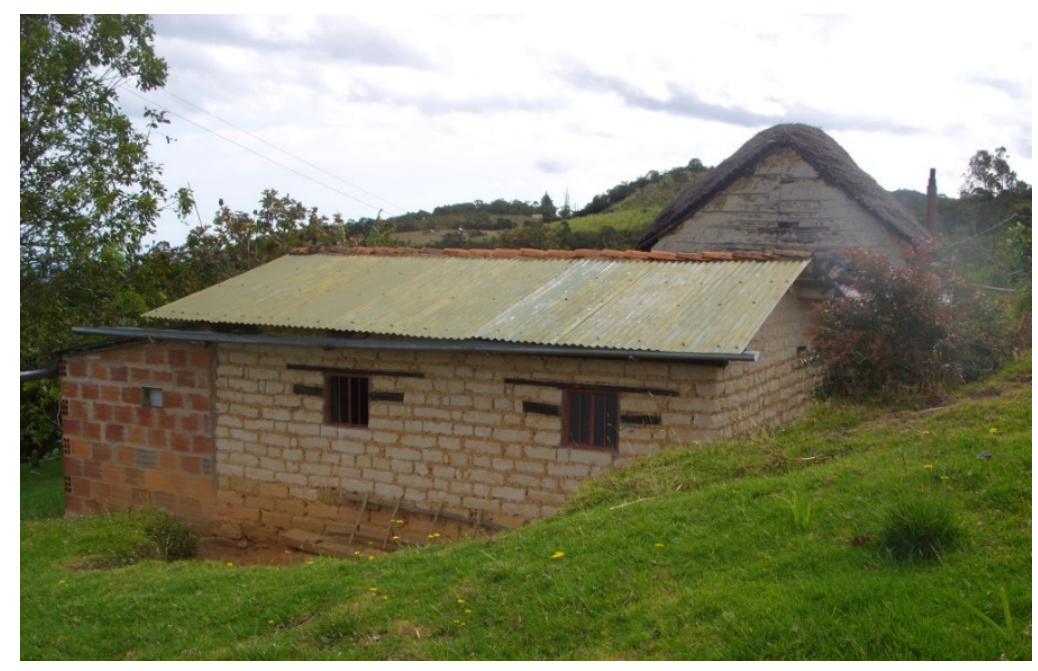

Figure 4: Daub masonry combined with industrial materials in the Dry Forest of the municipality of Gachantivá. In the background, a building with a straw roof. 
The relative low proportion of mud used in adobe blocks, its production process as well as drying times or proportion of aggregates into the whole mixture [18] do not comply in many cases with all the requirements defined by technical standards. Since adobe blocks are produced following oral tradition and adapted according to the specific conditions of each terrain, they do not comply with the more recent norms, so it is interesting to probe how popular knowledge (transmitted from generation to generation) yields buildings which have been standing for decades.

Approximately $88 \%$ of the houses visited still evidence volumes built with this technique, proportionally distributed in the above-mentioned three life zones.

\subsection{Stone masonry}

Houses that present this raw material were identified particularly in the Dry Forest zone of the municipalities of Ráquira, Sutamarchán and Sáchica (located in the south of the studied area). Stone masonry is commonly used in conjunction with wattle and daub walls, and it is one of the first techniques applied by homeowners with low economical resources (see Fig. 5). Despite the reduced number of volumes built with this material $(12.9 \%$ of the houses visited), this is a technique currently in force; during fieldwork, a five-year-old stone masonry volume was registered as part of a dwelling conformed by volumes recently built with other techniques.

\subsection{Earth, straw and clay tile roofing}

A traditional roof comprises a wooden structure over which a layer of cane intertwined with a specific type of straw (similar to Spartina Spartinae) has been installed; appropriate maintenance guarantees a useful life of at least 40 years. A variation consists of a wooden boarding over which earth is poured, mixed with straw, thin tree branches and gravel (see Fig. 6). Clay tiles are also used, but their cost is relatively high (for most of the population).

The number of buildings with earth or straw roofs identified during the fieldwork was minimal. Over the years, these materials were initially replaced with clay tiles (as the government improved roads and prices decreased), and in recent years with asbestos-cements sheets due to their low price, no maintenance demand and its use in State housing improvement programs.
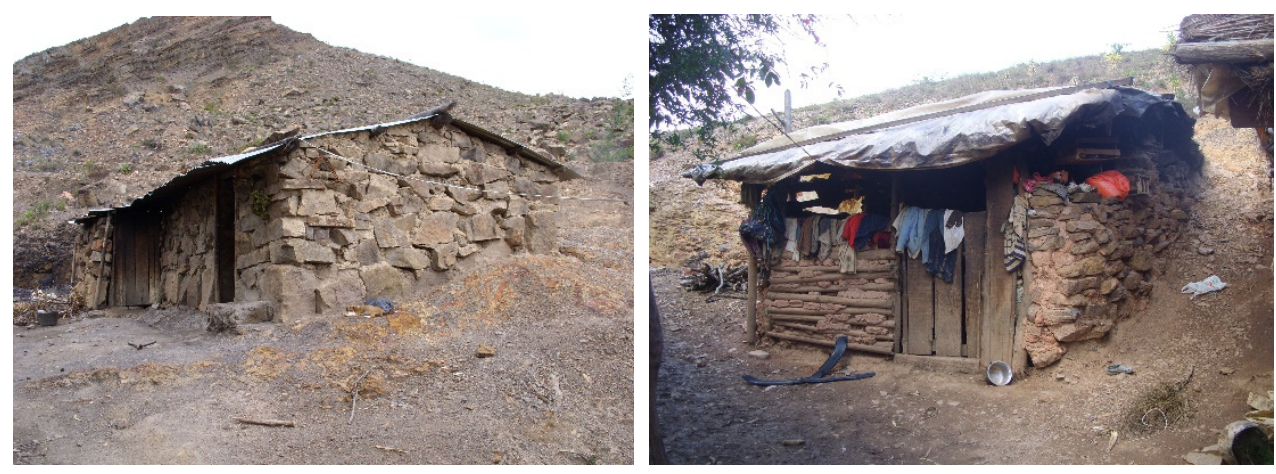

Figure 5: Uses of the stone masonry in the Dry Forest of the municipalities of Sáchica (left) and Sutamarchán (right). Approximately a half of the total number of houses built with this technique were found in this life zone. 


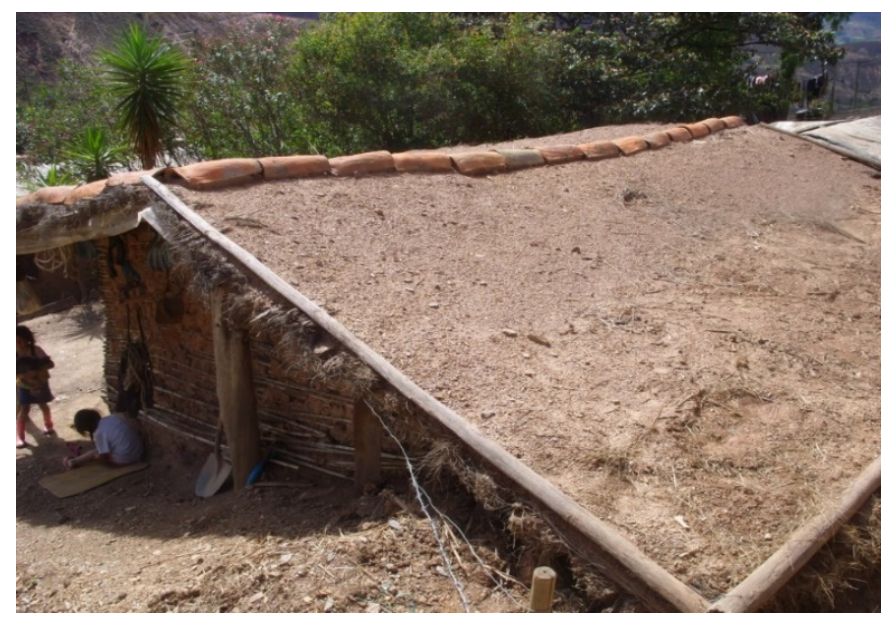

Figure 6: Volume built with wattle and daub walls system and an earth, straw and gravel roofing in the Dry Forest of the municipality of Sutamarchán. This construction is adapted to the inclined topography of its location.

\subsection{Wood and vegetal fibres}

Intensive use and subsequent shortage of native species made the introduction of grown timber such as eucalyptus (Eucalyptus globulus) necessary. This generated some new dynamics in the construction of rural houses, but with visible consequences that affect the family economy as it brings along a premature deterioration of structural components such as columns and beams. Regularly homeowners complain of wood pieces that have not had enough time to dry and of their low capacity to repeal insects which obligates their replacement barely fifteen or twenty years after their installation. State housing improvement programs have opted to replace the wooden elements for concrete and metal, so this material is disappearing from vernacular rural housing, not only from roofs, columns and beams, but also from windows and doors.

On the other hand, vegetal fibres such as furcraea cabuya and stipa ichu are used not only as raw material for handcrafts, but also to tie up wooden structural elements, which give a stronger resistance over time. Although the local names of these fibres can vary among the municipalities, they have the same performance.

\section{ABANDONMENT OF TRADITIONAL CONSTRUCTION SYSTEMS. CAUSES AND CONSEQUENCES}

\subsection{New industrial techniques}

Testimonies of inhabitants and builders confirm that industrial materials and techniques arrived in this area since 2000. Up until then, spatial distribution of the dwellings had not changed much since the sixteenth century. State policies, which intend to introduce improvements of sanitary conditions for dwellings, historically considered deficient [19], had a broad influence on the modification of the tectonic characteristics of houses.

Thereby, adobe masonry was replaced with solid or hollow brick masonry, clay tiles with asbestos-cement sheets, and wood disappeared from windows and doors and was substituted 
with aluminium and iron elements. The improvement of roads has allowed access from once remote locations to industrial construction materials and by larger means of transport, while houses located in faraway zones and with difficult accessibility are likely to be abandoned and left to ruin once their occupants die.

The use of industrial materials also results in a decrease of the total cost of the houses and a faster construction process, making traditional systems nowadays more complicated (as it demands a previous and longer preparation of raw materials) and expensive. Thus, new volumes of the houses are made using these materials, and are destined for rooms, kitchens and sanitary uses, while the volumes built using traditional techniques such as adobe masonry or wattle and daub walls are used as deposits or guest rooms; a few years ago, such spaces would have been assigned a greater hierarchy within the house.

On the other hand, there are lower conditions of thermal comfort in these new volumes due to the scarce heat accumulation during the day in brick masonries and asbestos-cement sheets.

\subsection{Migration and population aging}

Economic difficulties have been historically linked to rural life in Colombia [20], [21], and have continuously expelled peasants to the biggest cities or most important municipalities, looking for the best personal growth opportunities. This situation is more evident in those towns or rural areas not connected by national or interstate highways, as happens in some of those located in the area of study. According to the National Agricultural Census [22], the percentage of single-person households in the region is $22.5 \%$, which is above the national average, while the number of inhabitants in each dwelling is barely 2.91 (under the abovementioned average).

The same data affirms that the elderly population (sixty years or more) represents $50 \%$ of the inhabitants of rural houses, while $63 \%$ of the buildings are permanently occupied. In most cases, older habitants are in charge of the dwellings' maintenance activities, to which is added the difficult economic conditions of rural zones in Colombia and natural health problems in this type of population.

The lack of proper maintenance and the abandonment or replacement of volumes built with traditional systems brings with it the fact that $20 \%$ of houses are in a poor state of conservation.

\subsection{Pricing of traditional materials and construction systems}

Due to a lower market demand, traditional materials and techniques, once considered as belonging to the population with less economic resources, are now preferred for the construction of luxury houses and have risen in price. As a testimony of this situation, in the last fifteen years many homeowners in rural zones of municipalities, such as Villa de Leyva (located near the studied area), have built their country houses using Compressed Earth Block, a sophisticated version of adobe blocks produced by enterprises with a broad operative capacity. So, in recent years this version of mudbrick and houses are now a predominant image in the landscape; however, this new aesthetical expression stems from architects' designs that, in most cases, ignore the traditional typologies.

The high pricing of traditional materials has induced homeowners in the rural zones to use industrial materials, breaking with the traditional aesthetic; however, they adapt them to maintain their own ways of using their spaces. 


\subsection{Disappearance of traditional builders}

With the exception of the municipalities of Ráquira and Sáchica (where raw materials and traditional techniques are still in use), it was noted during fieldwork how in Arcabuco, Gachantivá, Tinjacá and Sutamarchán, municipalities with an extended use of new materials and techniques, traditional builders recognized by the community are elderly or have passed away. Although many inhabitants have participated in the construction process of their own home, even in their childhood, it is no longer possible to find young or mature people who still use the above-mentioned traditional systems. As a consequence, social memory associated with vernacular rural housing in this zone is mutating.

\section{TOWARDS A NEW CONCEPT OF VERNACULAR RURAL HOUSING IN THE ANDEAN HIGHLANDS OF COLOMBIA}

In the last fifty years, vernacular architecture has been a study field that has aroused the interest of a large number of researchers (initially anthropologists, later architects); nonetheless, there is no consensus on its definition. The Charter on Built Vernacular Heritage [23] seemed to unify different notions, but the analysis of local communities' dynamics suggest a revision of this Charter is required; more recently, Paul Oliver proposes not to engage with the idea of vernacular architecture as a traditional form of building (using traditional materials and techniques), but as buildings that embody tradition as a traditional form of occupying space (incorporating industrial materials). Also, concepts like "hybridization" [24], more adjusted to the reality of the market economy, the unfinished character of the houses and the incorporation of new construction systems, have begun to be used. This concept must be understood as the inclusion of new elements as a formal expression created by the inhabitants, without any intervention by professionals (see Fig. 7); although this circumstance has changed some cycles in familiar and community life.

\section{CONCLUSIONS}

Rural vernacular housing is constantly changing and, as a consequence, it is open to the entry of new construction systems. In this case study, socioeconomic considerations have a greater impact on the houses' type of building materials and techniques than environmental reasons; there is an influence, but there is not an inextricable link between environment, shape and materials.

Nonetheless, with the existence of a similar space program in many cases, the variety of raw materials used for the construction of rural vernacular houses in a relatively small area is striking; this is represented in a broad repertoire of aesthetic expressions.

State housing programs and individual improvement initiatives have helped to preserve, in some cases, consciously or unconsciously, the spatiality of traditional buildings; nonetheless, traditional building systems have changed, perhaps irreversibly. Although raw materials are still available in many cases, their rise in price has forced homeowners to look for alternatives.

Raw materials and traditional building systems have historically been considered as a source of illness and poverty by the State, sub-estimating their cultural values, ignoring their role in community cohesion and discouraging their use among homeowners. In effect, the introduction of new materials and the disappearance of traditional techniques and builders have resulted in a social memory's mutation; community participation is no longer necessary in the house's building process and traditional knowledge is being lost among young people. 


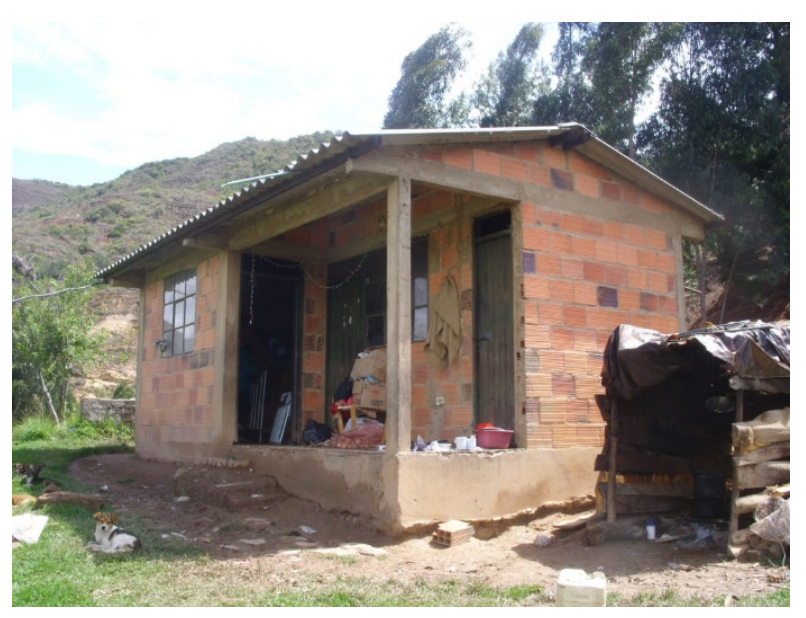

Figure 7: Volume built with industrial materials provided by the State in the Dry Forest of the municipality of Sutamarchán. Its homeowners built it, keeping some traditional spaces.

Nonetheless, the replacement of techniques such as wattle and daub walls and adobe masonry is not as harmful to the preservation of vernacular rural housing's traditional cultural values as the spatial modifications introduced in some State proposals, which are being rejected over time by homeowners because of alterations to the traditional use of their spaces.

While transculturation processes preserve values for the cultures from where they originate from [1], hybridization as a regional phenomenon influenced by market economy tends to homogenize the vernacular rural housing's tectonic characteristics, not only in this area but also in other countries, eliminating important features that make this type of architectonical expression unique.

\section{REFERENCES}

[1] Ortiz, F., Del fenómeno social de la "transculturación" y de su importancia en Cuba. www.fundacionfernandoortiz.org/downloads/ortiz/Del_fenomeno_social_de_la_trans culturacion.pdf

[2] Arango, S., Historia de la Arquitectura en Colombia, Centro Editorial y Facultad de Artes Universidad Nacional de Colombia: Bogotá, pp. 17-35, 1989.

[3] Simón, P., Noticias Historiales de la Conquista de Tierra Firme en la Indias Occidentales. Volumen 3, Banco Popular: Bogotá, pp. 155-319, 363-456, 1981.

[4] Boada, A.M., Organización social y económica en la aldea muisca El Venado - valle de Samacá, Boyacá. Revista Colombiana de Antropología, 35, pp. 118-145, 1999.

[5] Falchetti, A.M., Arqueología de Sutamarchán, Departamento de Antropología Universidad de Los Andes: Bogotá, 1972.

[6] Henderson, H. \& Ostler, N., Muisca settlement organization and chiefly authority at Suta, Valle de Leyva, Colombia: A critical appraisal of native concepts of house for studies of complex societies. Journal of Anthropological Archaeology, 24, pp. 148-178, 2005. www.journals.elsevier.com

[7] Langebaek, C.H., Arqueología Regional en el Valle de Leiva. Proceso de Ocupación Humana en una Región de los Andes Orientales de Colombia, Instituto Colombiano de Antropología e Historia: Bogotá, 2000. 
[8] Ramírez, M.C. \& Sotomayor, L., Subregionalización del altiplano cundiboyacense: Reflexiones metodológicas. Revista Colombiana de Antropología, XXVI, pp. 173-201, 1988.

[9] Gutiérrez de Alba, J.M., Impresiones de un viaje a América. Diario Ilustrado de Viajes por Colombia 1871-1873, Villegas Editores: Bogotá, p. 189, 2012.

[10] Fonseca, L. \& Saldarriaga, A., La Arquitectura de la Vivienda Rural en Colombia. Volumen 1, Centro de Estudios Ambientales: Bogotá, pp. 7-103, 147-173, 1980.

[11] Holdridge, L., Ecología Basada en Zonas de Vida, Instituto Interamericano de Cooperación Para la Agricultura: San José, 1987.

[12] Castellanos, D. \& Salinas, N., Libro Rojo de Plantas de Colombia. Especies Maderables Amenazadas I Parte. Versión Preliminar, Instituto Amazónico de Investigaciones Científicas. Ministerio de Ambiente, Vivienda y Desarrollo Territorial: Bogotá, 2006.

[13] Anderson, S., Memory without monuments: Vernacular Architecture. Traditional Dwellings and Settlements Review, 11, pp. 13-22, 1999.

[14] Rapoport, A., Vivienda y Cultura, Editorial Gustavo Gili: Barcelona, 1972.

[15] González, A., El dominio del entorno. Entorno y Cultura. Reflexiones Sobre Arquitectura, Urbanismo y Patrimonio, Universidad Autónoma Metropolitana: México DF, pp. 74-138, 1971.

[16] Asociación Colombiana de Ingeniería Sísmica, Manual de Evaluación, Rehabilitación y Refuerzo de Viviendas de Bahareques Tradicionales Construidas con Anterioridad a la Vigencia del Decreto 052 de 2002, Red de Solidaridad Social-Presidencia de la República: Bogotá, pp. 3-9, n.d.

[17] Fernández, M., Caracterización de Adobes. Alto Ricaurte, Análisis de Laboratorio, 2016.

[18] Craterre, Construir con Tierra. Tomo I, Fondo Rotatorio Editorial: Bogotá, 1990.

[19] Ancízar, M., Peregrinación de Alpha. Por las Provincias del Norte de la Nueva Granada, en 1850-51, Empresa Nacional de Publicaciones: Bogotá, pp. 293-324, 1956.

[20] Fals, O., El hombre y la Tierra en Boyacá. Desarrollo Histórico de una Sociedad Minifundista, Editorial Punta de Lanza: Bogotá, 1973.

[21] Fals, O., Campesinos de Los Andes, Editorial Iqueima: Bogotá, 1961.

[22] Ministerio de Agricultura y Desarrollo Rural, Censo Nacional Agropecuario 2013-2014. Características de la Vivienda y Sociodemográficas de la Población Residente en el Área Rural Dispersa Censada, DANE, Ministerio de Agricultura: Bogotá, 2015.

[23] Icomos, Carta de patrimonio vernáculo construido, 1999. www.icomos.org/charters/ vernacular_sp.pdf

[24] Ettinger, C., La Transformación de la Vivienda Vernácula en Michoacán. Materialidad, Espacio y Representación, Consejo Nacional de Ciencia y Tecnología. Gobierno del Estado de Michoacán de Ocampo/Consejo Estatal de Ciencia y Tecnología. Universidad Michoacana de San Nicolás de Hidalgo. El Colegio de Michoacán: Morelia, 2010. 